\title{
Ulcerative Colitis-Associated Colorectal Cancer Prevention by 5-Aminosalicylates: Current Status and Perspectives
}

\author{
Jean-Marie Reimund et al.* \\ Université de Caen Basse-Normandie, EA 3919, SFR ICORE, UFR de Médecine, \\ CHU de Caen, 14032 Caen Cedex 5, \\ CHU de Caen, Service d'Hépato-Gastro-Entérologie et Nutrition, \\ Pôle Reins - Digestif - Nutrition, 14033 Caen Cedex 09 \\ France
}

\section{Introduction}

Patients with ulcerative colitis (UC) are at increased risk of developing colorectal cancer. This risk increased mainly with longer duration of colitis, greater anatomic extent, and/or association to primary sclerosing cholangitis (PSC). Recent work highlighted also the carcinogenetic role of long-standing - despite if mild or moderate - mucosal inflammation, bringing an additional argument to support the growing concept of mucosal healing as the final target of current and future treatments (Lichtenstein \& Rutgeerts, 2010).

Until now, repeated colonoscopic surveillance with biopsies targeted on visible lesions associated to multiple random biopsies in endoscopically normal-appearing mucosa, remains the major way to detect mucosal dysplasia (a precancerous lesion), thereby decreasing colitis-associated cancer (CAC) mortality in UC patients. Colorectal cancer chemoprevention is a second promising strategy to reduce CAC risk in this patients' population. In particular, most of the available epidemiological data indicate a preventive role for 5-aminosalicylic acid derivatives (5-ASA), despite recent work suggested also a protective role for purine derivatives. Although the main mechanisms by which 5-ASA may reduce $\mathrm{CAC}$ risk is not exactly known and remains controversial, some interesting

\footnotetext{
* Marion Tavernier ${ }^{1,3}$, Stéphanie Viennot², Inaya Abdallah Hajj Hussein ${ }^{4}$, Benoît Dupont², Anne-Marie Justum ${ }^{2}$, Abdo R. Jurjus ${ }^{4}$, Jean-Noël Freund ${ }^{5}$ and Mathilde Lechevrel ${ }^{1}$

${ }^{1}$ Université de Caen Basse-Normandie, EA 3919, SFR ICORE, UFR de Médecine, CHU de Caen, Avenue Côte de Nacre, 14032 Caen Cedex 5, France

${ }^{2} \mathrm{CHU}$ de Caen, Service d'Hépato-Gastro-Entérologie et Nutrition, Pôle Reins - Digestif - Nutrition, 14033 Caen

Cedex 09, France

${ }^{3} \mathrm{CHU}$ de Caen, Service de Chirurgie Digestive et Viscérale, Pôle Reins - Digestif - Nutrition,

14033 Caen Cedex 09, France

${ }^{4}$ American University of Beirut, Department of Human Morphology, Riad El-Solh, Beirut, Lebanon

5INSERM U682, 3, avenue Molière, 67200 Strasbourg, France
} 
hypothesis have emerged, resulting from fundamental research in molecular biology and pharmacology. This increased understanding of the putative pathway(s) by which 5-ASA may interfere with CAC development appears also as the starting point for optimising 5-ASA derivatives or identifying new compounds acting more specifically and/or being more efficient in preventing neoplastic transformation of the colonic epithelium in UC patients. These different points will be addressed more precisely in the three next parts.

\section{Frequency of colorectal cancer risk in ulcerative colitis and risk factors}

Ulcerative colitis is a worldwide distributed inflammatory bowel disease (IBD). In a recent review, Cosnes et al., reported that in the West, its incidence and prevalence has increased in the past 50 years, respectively up to $8-14 / 10^{5}$ and $120-200 / 10^{5}$ persons (Cosnes et al., 2011).

\subsection{Frequency of colorectal cancer risk in ulcerative colitis}

Compared to the general population, patients with UC have an increased risk to develop colorectal cancer (Kulaylat \& Dayton, 2010; Viennot et al., 2009). Early data by Ransohoff estimate the risk of CAC at $0.5 \%$ per year after 10 years of UC, and $1.0 \%$ per year after 20 years of disease (Ransohoff, 1988). Later, a meta-analysis by Eaden et al. reviewing 116 studies representing a total of 54,478 UC patients, placed the risk of CAC in UC at $2 \%$ at 10 years, $8 \%$ at 20 years, and $18 \%$ at 30 years (Eaden et al., 2001). However, more recently published results, in particular those reporting general population data (in comparison to studies performed in reference centres), suggest that the risk may probably not be so high as reported earlier. This has been the case in a large population-based study by Bernstein et al. in Canada (Manitoba district), were the CAC risk was estimate to be 2.75 increased (95\% CI: 1.91-3.97) (Bernstein et al., 2001). In a large study from Denmark (22,290 person-years), Winter et al. reported a 30-year cumulative probability of CAC in UC of $2.1 \%$, a risk not statistically different than in the general population (Winther et al., 2004). Finally, Rutter et al. reported a cumulative CAC incidence of $2.5 \%$ at 20 years, $7.6 \%$ at 30 years, and $10.8 \%$ after 40 years following disease onset (Rutter et al., 2006). However, this study has been performed in a reference centre. This change in risk magnitude reflects probably a change in clinical practice such as a more often use of surveillance colonoscopy, a more systematic use of chemoprevention, and the fact that in several countries surgery was more commonly used in UC treatment than before the advent and progresses in total colectomy or coloproctectomy with either ileorectal or ileoanal anastomosis. However, the influence of other factors (e.g. environmental factors) cannot be excluded. Taking together 48 studies critically appraised for study population type, person years at risk, disease localisation in Crohn's disease (CD) and censoring for colectomy, Lutgens et al. found a cumulative risk in all IBD patients in population-based studies of $1 \%, 2 \%$ and $5 \%$ after 10,20 or more than 30 years of disease, with a pooled standardised morbidity ratio (SMR) of 3.6 (95\% CI: 3.1$4.1)$, compared to $1 \%, 11 \%$ and $43 \%$, and a pooled SMR of 8.8 (95\% CI: $7.3-11)$ in reference centres studies (Lutgens et al., 2008). In UC pooled SMR was also higher in reference studies (9.0, 95\% CI: 7.4-11.1) compared to 3.7 (95\% CI: 3.3-4.3) in population-based studies (Lutgens et al., 2008). 


\subsection{Factors increasing colorectal cancer risk in ulcerative colitis patients}

A number of studies have identified clear risk factors exposing UC patients to CAC risk. Most of these factors are inherent to the disease, although possible genetic factors may contribute to increase this risk. The identification of these factors is of outstanding importance, as it will allow us to better define the patients at high risk, representing the target population for colonoscopic surveillance and chemoprevention.

\subsubsection{Age of onset and duration of disease}

Patients with disease onset at an early age have been shown to be at higher risk of CAC. For example, Ekbom et al. estimated that patients with UC diagnosed before the age of 15, have a $40 \%$ risk of CAC after 35 years of disease onset compared to a $25 \%$ risk in patients with UC diagnosed between age 15 and 39 (Ekbom et al., 1990). However, the role of age at UC diagnosis alone remains controversial, as most authors suggest that this increased risk results probably (at least in part) from a longer UC duration. Before 8 to 10 years of UC progression, despite a study by Lutgens et al. reporting early occurring CAC (Lutgens et al., 2008), it is currently assumed that the risk of colorectal cancer is not different than the risk for sporadic colorectal cancer in the general population (Eaden et al., 2001; Rutter et al., 2006; Ekbom et al., 1990). It is only later that it increases by approximately 0.5 to $1 \%$ each year, reaching the incidence rates reported in Section 2.1.

\subsubsection{Disease extension}

Extension of colonic disease is a second really important independent risk factor, CAC occurring principally in UC patients having a history of pancolitis or at least of extended colitis (i.e. colitis beyond the left colonic angle). In these patients, relative risk (RR) is about 14.8 (95\% IC: 11.4-18.9) compared to 2.8 (95\% IC: 1.6-4.4) in patients with left sided UC and 1.7 (95\% CI: 0.8-3.2) when disease is limited to the rectosigmoid. In case of proctitis, CAC risk is virtually not higher than in the general population (Ekbom et al., 1990).

\subsubsection{Family history of colorectal cancer}

A family history of colorectal cancer increases slightly the CAC risk in UC patients (Nuako et al., 1998; Askling et al., 2001a). By contrast, having a first-degree relative affected by UC does not increase the risk for colorectal cancer among other healthy family members (Askling et al., 2001b).

\subsubsection{Presence of backwash ileitis}

The presence of reflux (or backwash) ileitis has been suggested by several authors to increase CAC risk (Heuschen et al., 2001). However, it remains controversial as other studies found no relation between backwash ileitis and risk for CAC (Rutter et al., 2006a).

\subsubsection{Association with primary sclerosing cholangitis}

Until now, the most important risk factor for CAC in UC patients is the presence of concomitant PSC (for review see: Torres et al., 2011), even this association occurs only in a minority of patients. For example, a case-control study performed by Broome et al. reported a cumulative CAC risk of $9 \%$ after 10 years, 21\% after 20 years and 50\% after 25 years in patients having both UC and PSC, compared with $2 \%, 5 \%$ and $10 \%$ in patients with only UC 
(Broome et al., 1995). More recently, Sokol et al. showed a 25-year cumulative rate of CAC of $23.4 \%$ in patients suffering both from IBD [ $\mathrm{n}=75$; final diagnosis: $42 \mathrm{UC}, 21 \mathrm{CD}, 1$ indeterminate colitis, 11 unclassified IBD (uIBD)] and PSC, compared to $0 \%$ in patients with IBD alone ( $\mathrm{n}=150$; final diagnosis: $80 \mathrm{UC}, 43 \mathrm{CD}, 3$ indeterminate colitis, 5 uIBD) $(P=$ 0.002), despite patients with both IBD and PSC had milder disease and a higher use of 5ASA $(P<0.001)$ (Sokol et al., 2008). Noteworthy, this risk remains even after liver transplantation for PSC treatment (Loftus et al., 1998).

\subsubsection{Chronic inflammation}

The impact of chronic inflammation and CAC has long been a matter of debate. In fact, from a theoretical point of view, increasing evidence supported the hypothesis that chronic inflammation contributes to colon carcinogenesis, in particular by generating a favourable microenvironment for cancer initiation, development, and progression. Increase in mucosal pro-inflammatory cytokine or other inflammatory mediators such as reactive oxygen and nitrogen species, or cyclooxygenase-2 (COX-2)-derived prostaglandins production results in alterations of a large number of molecules such as DNA, RNA, proteins or lipids. For example, they induce the formation of adducts to DNA, generating point mutations in genes like the $p 53$ tumour suppressor gene, which is early mutated in IBD inflamed mucosa (even before neoplastic transformation) (Laurent et al., 2011), and in CpG islands involved in DNA methylation. In addition, the increase in local tissue pro-inflammatory cytokines and prostaglandins inhibits apoptosis and favours cell proliferation, thereby facilitating carcinogenesis. Currently, both clinical and experimental data demonstrate that chronic inflammation represents probably a key factor in CAC pathogenesis. Rutter et al. indirectly suggest this relationship by showing that endoscopic features indicative of previous severe inflammation, such as pseudopolyps, or indicative of chronically active colitis such as shortened or tubular colon and stricture formation are associated with a significant increase in CAC (Rutter et al., 2004a). More direct clinical evidence came from studies by Rutter et al. and Gupta et al. (Rutter et al., 2004b; Gupta et al., 2007). Rutter et al. found that the endoscopically- and histologically-assessed severity of inflammation significantly enhanced the risk of CAC (2.5 and 5.1 respectively) (Rutter et al., 2004b). More recently, a cohort study by Gupta et al. reported a significant link between histological inflammation and progression towards high-grade dysplasia or CAC, with a RR of 2 (Gupta et al., 2007). Finally, Garrity-Park et al. showed an association between myeloperoxydase immunochemistry, TNF- $\alpha$ polymorphism and RUNX3 methylation and CAC (Garrity-Park et al., 2011). In addition to these clinical data, experimental results contribute to clarify the underlying cellular or molecular mechanisms explaining the link between inflammation and colorectal carcinogenesis in UC patients. For example, excessive pro-inflammatory cytokine production increases the expression of COX-2 and 5-lipoxygenase (5-LOX) (Agoff et al., 2000). This effect will result in a decrease in the non-esterified arachidonic acid pool responsible for decreased apoptosis, therefore favouring tumorigenesis (Cao et al., 2000). Inflammatory mediators also influence suppressor gene activity; this has been demonstrated for macrophage inhibiting factor which suppresses p53 transcriptional activity in vitro (Hudson et al., 1999), a result which appears important as p53 immunopositivity (together with abnormal DNA ploidy) has been suggested to be an important risk factor of developing CAC in longstanding IBD (Gerrits et al., 2011). In addition, recently, 
experimental data clearly demonstrate the role of TNF- $\alpha$ as a key mediator in inflammationdriven CAC (Popivanova et al., 2008). The authors showed that invalidation of the p55 TNF$\alpha$ receptor dramatically reduced the colon tumour formation in mice treated by azoxymethane (AOM, a carcinogen instilled intrarectally) in dextran-sulphate (DSS)induced experimental colitis in mice. Moreover, wild type mice transplanted with bone marrow from TNF-Rp55-deficient mice appear less susceptible to develop colon tumours, whereas transplantation of bone marrow from wild type animals to TNF-Rp55-deficient mice does not significantly increase tumour formation compared to wild-type animals. Finally, etanercept administration (a monoclonal antibody blocking the p75 TNF- $\alpha$ receptor) reduced both tumour size and number in wild type mice both treated with AOM and DSS (Popivanova et al., 2008). Taken together, these results provide a strong rationale for chemoprevention in order to reduce the mucosal inflammation in longstanding UC patients, and appear as relevant arguments in favour of mucosal healing as a new goal for evaluation of therapeutic efficacy.

\subsection{Factors suspected to protect from colitis-associated cancer 2.3.1 Folate supplementation}

Several experimental and epidemiologic studies have suggested that low folate concentrations increase the risk to develop sporadic colorectal cancer, probably by inducing DNA strand breaks in the p53 tumour suppressor gene (Giovannucci et al., 1993; Giovannucci et al., 1998; Kim et al., 1997). Despite patients with IBD have an increased risk of folate deficiency (Phelip et al., 2008) - but more probably CD patients than UC patients (Yakut et al., 2010) -, until now only one case-control study (including 6 cases and 61 controls) found a significant protective effect of folate supplementation (Lashner, 1993) and one small 3 months pilot randomized placebo controlled trial reported a decrease in cell proliferation examined by immunohistochemistry in 12 UC patients (Biasco et al., 1997). All other found no effect of folate supplementation, which therefore could not be seriously considered as an effective chemopreventive treatment against CAC (Rutter et al., 2004b; Lashner et al., 1989; Lashner et al., 1997; Pardi et al., 2003).

\subsubsection{Ursodeoxycholic acid treatment}

Several years ago, ursodeoxycholic acid (UDCA) treatment has been considered as playing a protective role against CAC in patients with both UC and PSC. Harnois et al. found that high-doses of UDCA (13-15 mg/ kg body weight/day) increased the 4-year survival of these patients (Harnois et al, 2003). Concerning CAC, Pardi et al, studying 52 patients with UC associated to PSC, reported that UDCA treatment ( $\mathrm{n}=29$ patients, $13-15 \mathrm{mg} / \mathrm{kg}$ body weight/day for a median of 42 months) decreased dysplasia or CAC risk compared to placebo (10\% versus $35 \%$ after an average follow-up of 6.5 years; RR $=0.26,95 \%$ CI: 0.07 0.99) (Pardi et al., 2003). However, this result contrasts with studies by Sjöqvist et al. and Wolf et al. which found no protective effect of UDCA (Sjöqvist et al., 2004; Wolf et al., 2005). In addition, higher doses of UDCA (28-30 mg/ $\mathrm{kg}$ body weight/day) have been recently associated to an increased risk of CAC in UC patients with PSC (Eaton et al., 2011). Therefore, at the present time, the protective role of UDCA remains controversial and it could not be recommended as a chemopreventive treatment, at least at doses higher than 15 $\mathrm{mg} / \mathrm{kg}$ body weight/day. 


\section{Chemoprevention by 5 -aminosalicylic acids}

\subsection{5-aminosalicylates basic pharmacology}

Sulphasalazine is the original 5-aminosalicylate (5-ASA)-containing medication used in UC. Chemically, named salicylazosulphapyridine (SASP), it combines two molecules with different properties, sulfapyridine (SP), which has a bacteriostatic activity, and 5-ASA (or mesalazine), the moiety having the anti-inflammatory properties. These two compounds were linked together by an azo bond (Azadkahn et al., 1982). After an oral intake, only a small portion of SASP is absorbed in the small intestine and the bulk of the sulphasalazine reaches the colon intact, where colonic bacterial azoreductase enzymes cleave the azo bond with the subsequent liberation of SP and 5-ASA. As SP seems to be responsible for most of the SASP side effects, new approaches for delivering only 5-ASA have emerged, either using pro-drugs (olsalazine, balsalazide) or oral mesalazine formulations "protecting" 5-ASA from release, absorption, and metabolism in the stomach and proximal small bowel by delayed release (Asacol ${ }^{\circledR}$, Salofalk $\AA$, Mesasal ${ }^{\circledR}$, Claversal $\left.{ }^{\circledR}\right)$ or controlled release mechanisms (Pentasa $\left.{ }^{\circledR}\right)$ (Chourasia \& Jain, 2003; Sandborn \& Hanauer, 2003). Free 5-ASA administered orally undergoes rapid and nearly complete absorption from the distal ileum or colon (actually depending on concentration and local $\mathrm{pH}$ ), followed by extensive metabolism to N-Acetyl-5-ASA (N-Ac-5-ASA) by the N-acetyltransferase 1 (NAT 1) in intestinal epithelial cells and the liver (Sandborn \& Hanauer, 2003). A mixture of free 5-ASA and N-Ac-5-ASA is excreted in the urine (Mardini et al., 1987; Rijk et al., 1988; Vree et al., 2000). Only 5-ASA is therapeutically active, some placebo-controlled trial in UC patients having shown that the N-Ac-5-ASA metabolite is inactive (van Hogezand et al., 1988).

\subsection{Clinical data}

In a retrospective case-control study comparing 102 UC patients with CAC to 196 cancerfree UC patients, Pinczowski et al. provided the first evidence for a role of aminosalicylates in CAC prevention (Pinczowski et al., 1994). They found an independent chemoprotective effect for sulfasalazine taken for at least 3 months with an odds ratio of 0.38 (95\% CI: 0.2-0.69 after adjusting for disease activity) (Pinczowski et al., 1994). In an other retrospective study by Moody et al., the crude proportion of UC patients developing CAC was of $3 \%$ in those taking long-term 5-ASA compared to 31\% in those who stopped their treatment or had poor compliance with 5-ASA therapy $\left(\chi^{2}=20.2, P<0.001\right)$ (Moody et al., 1996). Several years later, Eaden et al. confirmed these findings in a retrospective case-control study: in UC patients, continuous treatment (defined as a treatment for 5 to 10 years) with 5-ASA reduced the CAC risk, at least by 75\% [Odds ratio (OR): 0.75, 95\% CI: 0.13-0.48] (Eaden et al., 2000). Even after adjustment for other potentially most influential variables, this reduction was the highest in patients taking mesalazine at doses $>1.2 \mathrm{~g} /$ day (OR: 0.19; 95\% CI: 0.04-0.60), whereas SASP at a dose of $2 \mathrm{~g}$ / day or more was not effective (OR: 0.85, 95\% CI: 0.32-2.26) (Eaden et al., 2000). Nevertheless, this study had two important drawbacks as cases and controls were not always taken from the same population and as they differed by their ethnic composition. However, more recently, studies by Velayos et al., van Staa et al., and Terdiman et al., brought additional data to reinforce the hypothesis that regular use of 5ASA may reduce the risk of CAC in UC patients (Velayos et al., 2005; Velayos et al., 2006; 
van Staa et al., 2005; Terdiman et al., 2007). Velayos et al. first performed a meta-analysis on 9 ( 3 cohort and 6 case-control) studies including 334 CAC cases and 140 cases of dysplasia, and found a protective effect of 5-ASA for CAC risk (OR: 0.51, 95\% CI: 0.380.69 ), but not for risk of dysplasia (OR: 1.18, 95\% CI: 0.41-3.43; but only 2 studies evaluated this outcome) (Velayos et al., 2005). They confirmed these results in a casecontrol study (188 CAC compared to matched controls) showing a significant decrease in CAC risk in patients taking 5-ASA for 1 to 5 years (OR: 0.4, 95\% CI: 0.2-0.9) (Velayos et al., 2006). However, this protective role for 5-ASA use for more than 6 years (6 to 10 years) does not remain statistically significant (6 to 10 years OR: $0.6,95 \%$ CI: $0.3-1.4 ;>10$ years OR: 0.6, 95\% CI: 0.3-1.3) (Velayos et al., 2006). In 2005, van Staa et al. conducted a large population-based study (18,969 patients, 100 with CAC despite 5-ASA use), and distinguished patients considered as 5-ASA regular users (if they had 6 or more 5-ASA prescriptions in the previous 12 months) and non-regular users. Their results could be summarized as followed: (1) regular users had a lower CAC risk (OR: 0.7, 95\% CI: 0.441.43), (2) this effect does not occur in SASP users, and (3) for mesalazine regular users this protective effect was only statistically significant in patients with 13-30 prescriptions (OR: 0.30, 95\% CI: 0.11-0.84). Finally, Terdiman et al. in a stratum-specific case-control study reported a trend towards a reduced CAC risk related to increasing number of mesalamine prescription, but this tendency was not statistically significant $(p=0.08)$ and the authors were not definitively confident regarding the CAC protective properties of 5-ASA treatment (Terdiman et al., 2007).

This doubt was reinforced by additional data published during the last 4 years, and clearly brought some confusion into clinicians' mind concerning the real effect of 5-ASA in CAC prevention, despite they have been considered as protective by several health authorities. Bernstein et al. in a population-based survey in Canada (Manitoba University) among 4,325 UC patients and 4,419 CD patients with colonic disease, found no difference in CAC between patients using 5-ASA for more than 1 or 5 years (OR: 1.02, 95\% CI 0.60-1.74 and OR: $1.96,95 \%$ CI $0.84-4.55$ respectively), with a similar mean number of 5-ASA prescriptions at 10 vs. $11(p=0.8)$ and a similar mean number of dose days at 330 vs. $410(p=0.69)$ (Bernstein et al., 2011).

Unfortunately, it would probably not be possible to conduct a prospective doubleblinded, placebo-controlled trial to definitively prove or infirm the chemopreventive role of 5-ASA against CAC; regarding the slow CAC increased risk in the general UC population, such a study needed a too important number of patients and a too long period of surveillance. Cost-effectiveness, as well as its impact on clinical practice to prevent $\mathrm{CAC}$, of such a study seems not realistic and will probably never been performed. Therefore, clinicians have to weight the risk/benefit balance of CAC chemoprevention using 5-ASA, and to consider more attentively other strategies increasing their ability to decrease CAC development and morbidity or mortality in UC (and in general colonic IBD) patients (see Chapter 4.).

\subsection{Mechanisms of action}

As stated above, despite current controversy, clinical data suggest that 5-aminosalicylates may have antineoplastic and potentially chemopreventive properties. It is hypothesized that 5-aminosalicylates may have roughly similar genetic and molecular targets as nonsteroidal 
anti-inflammatory drugs (NSAIDs), including interactions with ROS production, with the COX and LOX cascade, with the activation of the transcription factor nuclear factor (NF)- $\mathrm{\kappa B}-$ dependent effects, and with the peroxisome proliferator-activated receptor- $\gamma$ (PPAR- $\gamma$ )dependent pathway.

\subsubsection{Oxidative stress and DNA damage: role in UC-associated CRC carcinogenesis}

Oxidative stress is a common consequence of inflammatory and immune activation. Several experimental data have shown that oxidative stress, by affecting both DNA damage and DNA repair processes, and by activating key genes are involved in several inflammatory and carcinogenetic pathways, contributing particularly to epithelial cells neoplastic transformation (Hussain et al., 2003; Boland et al., 2005). In aerobic cells, reactive oxygen species (ROS) are generated as a byproduct of normal mitochondrial activity. However, inflammation induces an increased mitochondrial oxidative metabolism resulting in an enhanced ROS production [e.g. superoxide anion radical $\left(\bullet \mathrm{O}_{2}^{-}\right)$, hydrogen peroxide $\left(\mathrm{H}_{2} \mathrm{O}_{2}\right)$, hydroxyl radical $(\bullet \mathrm{OH})$, as well as nitric oxide (NO)] (Boland et al., 2005). These ROS cause major damage to cellular macromolecules, including DNA alterations. Increased expression of ROS and NO [or NO-synthase (NOS), the enzyme which drives NO production from arginine] has been reported in inflamed mucosa from UC or CD patients (Hussain et al., 2000; Oshitani et al., 1993; Rachmilewitz et al., 1995; Kimura et al., 1998; Hofseth et al., 2003). The role of oxidative stress in CAC development has also been suggested. D'Inca et al. reported increased levels of 8-hydroxydeoxyguanosine (8-OHdG: a mutagen formed by the effect of $\bullet \mathrm{OH}$ at the $\mathrm{C} 8$ position of deoxyguanosine base) in colonic mucosa in UC patients compared to normal mucosa in healthy controls. Furthermore, 8-OHdG concentrations were higher in UC patients with dysplasia, with longer disease duration, and with clinical and histological activity, and were lower in the rectum, suggesting that the 5-aminosalicylate enemas used by most of the study patients might have had an antioxidant effect ( $\mathrm{D}^{\prime}$ Inca et al., 2004). Other evidence supporting the contribution of oxidative stress to colorectal carcinogenesis came from the study by Hussain et al. examining the mutation spectrum of p53 tumour suppressor gene at codons 247 and 248. They found in more than 50\% of colonic mucosal specimens from UC patients, a higher frequency of $\mathrm{G}$ to A transitions at the CpG site of codon 248 and C to T transitions at the third base of codon 247 (Hussain et al., 2000). In addition, these abnormalities were only detected in inflamed mucosa (Hussain et al., 2000). Finally, alterations of $p 53$ were associated with increased iNOS activity suggesting that oxidative stress plays a role in colorectal carcinogenesis (Oshitani et al., 1993). An exhaustive overview on this specific topic has been recently published (Roessner et al., 2008).

Numerous reports have suggested that oxidative stress may play a role in colon carcinogenesis. In colon cancer cell lines, ROS such as $\bullet \mathrm{O}_{2^{-}}, \bullet \mathrm{OH}$, hypochlorite anion, and, in particular $\mathrm{H}_{2} \mathrm{O}_{2}$ induce frameshift mutations and inactivate the DNA mismatch repair system (Gasche et al., 2001; Chang et al., 2002). Concerning this point, several studies indicate that mesalazine is able to inhibit ROS production and/or their deleterious effects (Allgayer et al., 1992; Allgayer, 2003).

\subsubsection{5-aminosalicylates and cyclooxygenase-2 inhibition}

As stated in Section 2.2.6 COX-2 represents an important target in colorectal cancer in general, and CAC in particular. Due to its structural similarity with other COX inhibitors 
and to the over-expression of COX-2 in inflamed UC colonic mucosa, it has been suggested that 5-ASA chemoprotective properties against CAC were linked to its capacity to inhibit COX-2 activity. However, experimental data remain controversial. In an experimental study published by Stolfi et al., 5-ASA effectively inhibited colon cancer cell line HCT-115 (which expresses constitutively COX-2) proliferation and, in addition, down-regulated COX-2 mRNA and protein expression, and finally decreased prostaglandin E2 production (Stolfi et al., 2008). However, addition of exogenous prostaglandin E2 to cell culture does not reverse 5-ASA's inhibitory effect on HCT-115 proliferation. Furthermore, Stolfi et al. showed that 5ASA inhibits proliferation in DLD-1 human colon cancer cell line (which does neither express COX-1, nor COX-2), a result we reproduced recently (unpublished data) (Stolfi et al., 2008). Therefore, inhibition of colon carcinogenesis by 5-ASA appears partially independent of its effects on COX-2.

\subsubsection{Peroxisome proliferator-activated receptor- $\gamma$ activation}

Peroxisome proliferator-activated receptor- $\gamma$ is a nuclear receptor highly expressed in the colonic mucosa. Several studies have demonstrated that its activation both decreased tumour cells proliferation and increased pro-apoptotic activities (Matthiessen et al., 2005; Shimada et al., 2002; ), inhibited aberrant crypt foci formation (Tanaka et al., 2001), and reduced colorectal cancer development (Osawa et al., 2003), presumably through an interaction with the Wnt/ $\beta$-catenin pathway (Jansson et al., 2005; Lu et al., 2005). Rousseaux et al. have demonstrated that 5-ASA acts like a PPAR- $\gamma$ ligand (Rousseaux et al., 2005). Performing both in vitro and in vivo animal experiments, they showed that 5-ASA increased PPAR- $\gamma$ expression, thereby reducing inflammation in experimental colitis in mice (Rousseaux et al., 2005). Additionally, Schwab et al. showed that the anti-proliferative and pro-apoptotic properties of 5-ASA were, at least partly, mediated by PPAR- $\gamma$-dependent mechanisms (Schwab et al., 2008). Finally, in immunodeficient SCID mice engrafted with human colorectal cancer cells, locally administered mesalazine significantly inhibited xenografts' growth, an effect blocked by concomitant administration of the PPAR- $\gamma$-selective antagonist GW9662 (Desreumaux \& Ghosh, 2006).

\subsubsection{5-aminosalicylic acid and nuclear factor NF-kappa B}

The clinical efficacy of 5-ASA as a chemopreventive drug against CAC may probably also be the result of its inhibition of the pro-inflammatory and pro-oncogenic nuclear factor kappa $B$ $(\mathrm{NF}-\kappa \mathrm{B})$. Nuclear factor- $\mathrm{\kappa B}$ is a transcription factor controlling the expression of numerous genes implicated both in inflammatory and immune response, and additionally in initiation, development and propagation of colorectal cancer in UC patients. Although few data are available, the key role of NF- $\kappa B$ both in regulating inflammatory/immune response in IBD patients, and its implication in colorectal carcinogenesis, pointed researchers interest towards its role in CAC. In particular, the close link between TNF- $\alpha$ (clearly recognized as a pro-carcinogen in $\mathrm{CAC}$ ) and NF- $\kappa \mathrm{B}$, suggested that NF- $\kappa \mathrm{B}$ probably contributes to CAC onset and development. Until now, this has only been shown in an animal study (Onizawa et al., 2009) and suspected from the results published by Popivanova et al. in 2008 (Popivanova et al., 2008; ). 


\subsubsection{Effects on the Wnt//-catenin and the epidermal growth factor receptor pathways}

Recent studies have hypothesized that 5-ASA may also exert its chemopreventive properties directly, and not only through its actions on mucosal inflammation. Mesalamine has been reported to decrease the activity of the wingless and integration site growth factor (Wnt)/ $\beta$-catenin pathway [which is constitutively activated in up to $80 \%$ of sporadic colorectal cancers due to somatic mutation of the Apc tumour suppressor gene, although lesser in CAC (Viennot et al., 2009; Laurent et al., 2011)], by inhibiting protein phosphatase A2 (which results in a enhancement of $\beta$-catenin phosphorylation, and induces activation of carcinogenetic genes such as cyclin D1,c-met and c-myc) (Bos et al., 2006).

5-aminosalicylic acid has also been reported to inhibit epidermal growth factor receptor (EGFR) pathway. This pathway has been shown to be highly activated in colorectal cancer, and is one of the targets of currently used biotherapies in sporadic colorectal cancer (cetuximab, Erbitux ${ }^{\circledR}$ ). In CAC, over-expression of EGFR is frequent (Svrcek et al., 2007), and in vitro human colon cancer cell lines exposure to 5-ASA markedly decreased EGFR signaling, at least in part by enhancing the activity of phosphatase SH-PTP2, one of the phosphatases inhibiting EGFR phosphorylation, an essential event for its pro-carcinogenetic effects (Moghal et al., 1999; Monteleone et al., 2006).

\section{Conclusion and current clinical recommendations}

Colitis-associated cancer prevention in UC (and colonic CD) remains a controversial subject. Following initial data reporting an important increase in colorectal cancer in UC patients, more recent studies performed not only in reference centres but also considering the general UC patients population, reported a CAC risk probably lower than the risk reported in earlier work. In addition, despite numerous (but also often contradictory experimental data on 5-ASA effects on colorectal cancer initiation, development and progression) suggesting a protective role of 5-ASA against CAC in UC patients, most of the data are retrospective, some data are contradictory, and a clear conclusion could not been drawn. In addition, it seems unlikely that a prospective, large population-based study to evaluate 5-ASA chemopreventive properties against CAC would be performed, due to its costs, duration, and number of patients needed to participate.

As a conclusion, clinicians should therefore be very cautious but also consider each UC (or colonic $(D)$ patient as a particular case. Nevertheless, in our opinion and despite several uncertainties, the best remains to follow practical guidelines recommended by numerous gastroenterological scientific societies. These guidelines usually propose a systematic chemopreventive use of 5-ASA (usually around 1.8 to $2 \mathrm{~g} /$ day) in addition to systematic colonoscopic dysplasia and CAC screening including chromoendoscopy using either indigo carmine or methylene blue.

\section{References}

Agoff, S.N.; Brentnall, T.A.; Crispin, D.A.; Taylor, S.N.; Raaka, S.; Haggitt, R.C.; Reed, M.W.; Afonina, I.A.; Rabinovitch, P.S.; Stevens, A.C.; Feng, Z. \& Bronner, M.P. (2000). The role of cyclooxygenase 2 in ulcerative colitis-associated neoplasia. The American Journal of Pathology, 157, 3, Septembre 2000, 737-745, ISSN: 0002-9440. 
Allgayer, H. (2003). Review article: mechanisms of action of mesalazine in preventing colorectal carcinoma in inflammatory bowel disease. Alimentary Pharmacology and Therapeutics, 18 (Suppl. 2), September 2003, 10-14, ISSN: 0269-2813.

Allgayer, H.; Höfer, P.; Schmidt, M.; Böhne, P.; Kruis, W. \& Gugler, R. (1992). Superoxide, hydroxyl and fatty acid radical scavenging by aminosalicylates. Direct evaluation with electron spin resonance spectroscopy. Biochemical Pharmacology, 43, 2, January 1992, 259-262, ISSN: 0006-2952.

Askling, J.; Dickman, P.W.; Karlén, P.; Brostrom, O.; Lapidus, A., Löfberg, R. \& Ekbom A. (2001a). Family history as a risk factor for colorectal cancer in inflammatory bowel disease. Gastroenterology, 120, 6, May 2001, 1356-1362, ISSN: 0016-5085.

Askling, J.; Dickman, P.W.; Karlén, P.; Brostrom, O.; Lapidus; A., Löfberg, R. \& Ekbom A. (2001b). Colorectal cancer rates among first-degree relatives of patients with inflammatory bowel disease: a population-based cohort study. Lancet, 357, 9252, January 2001, 262-266, ISSN: 0140-6736.

Azadkahn, A.K.; Truelove, S.C. \& Aronson, J.K. (1982). The disposition and metabolism of sulphasalasine (salicylazosulphapyridine) in man. British Journal of Clinical Pharmacology, 16, 4, April 1982, 523-528, ISSN: 0306-5251.

Bernstein, C.N.; Nugent, Z. \& Blanchard, J.F. (2011). 5-aminosalicylate is not chemoprophylactic for colorectal cancer in IBD: a population-based study. The American Journal of Gastroenterology, 106, 4, April 2011, 731-736, ISSN: 0002-9266.

Bernstein, C.N.; Blanchard, J.F.; Kliewer, E. \& Wajda, A. (2001). Cancer risk in patients with inflammatory bowel disease: a population-based study. Cancer, 91, 4, February 2001, 854-862, ISSN: 0008-543X.

Biasco, G.; Zannoni, U.; Paganelli, G.M.; Santucci, R.; Gionchetti, P. ; Rivolta, G.; Miniero, R.; Pironi, L.; Calabrese, C.; Di Febo, G. \& Miglioli, M. (1997). Folic acid supplementation and cell kinetics of rectal mucosa in patients with ulcerative colitis. Cancer Epidemiology Biomarkers \& Prevention, 6, 6, June 1997, 469-471, ISSN: 1055-9965.

Boland, C.R.; Luciani, M.G.; Gasche, C. \& Goel, A. (2005). Infection, inflammation, and gastrointestinal cancer. Gut, 54, 9, September 2005, 1321-1231, ISSN: 0017-5749.

Bos, C.L.; Diks, S.H.; Hardwick, J.C.; Walburg, K.V.; Peppelenbosch, M.P. \& Richel, D.J. (2006). Protein phosphatase 2A is required for mesalazine-dependent inhibition of Wnt/ $\beta$-catenin pathway activity. Carcinogenesis, 27, 12, December 2006, 2371-2382, ISSN: 0143-3334.

Broomé, U.; Löfberg, R.; Veress, B. \& Eriksson L.S. (1995). Primary sclerosing cholangitis and ulcerative colitis. Evidence for increased neoplastic potential. Hepatology, 22, 5, November 1995, 1404-1408, ISSN: 0270-9139.

Cao, Y.; Pearman, A.T.; Zimmerman, G.A.; McIntyre, T.M. \& Prescott, M. (2000). Intracellular unesterified arachidonic acid signals apoptosis. Proceedings of the National Academy of Sciences of the United States of America, 97, 21, October 2000, 11280-11285, ISSN: 0027-8424.

Chang, C.L.; Marra, G.; Chauhan, D.P.; Ha, H.T.; Chang, D.K.; Ricciardiello, L.; Randolph, A.; Carethers, J.M. \& Boland, C.R. (2002). Oxidative stress inactivates the human DNA mismatch repair system. American Journal of Physiology. Cell Physiology, 283, 1, July 2002, C148-C154, ISSN: 0363-6143. 
Chourasia, M.K. \& Jain, S.K. (2003). Pharmaceutical approaches to colon targeted drug delivery systems. Journal of Pharmacy \& Pharmaceutical Sciences, 6, 1, January-April 2003, 33-66, ISSN: 1482-1826.

Cosnes, J.; Gower-Rousseau, C.; Seksik, P. \& Cortot, A. (2011). Epidemiology and natural history of inflammatory bowel diseases. Gastroenterology, 140, 6, May 2011, 17851794, ISSN: 0016-5085.

D'Inca, R.; Cardin, R.; Benazzato, L.; Angriman, I.; Martines, D. \& Sturniolo, G.C. (2004). Oxidative DNA damage in the mucosa of ulcerative colitis increases with disease duration and dysplasia. Inflammatory Bowel Disease, 10, 1, January 2004, 23-27, ISSN: 1078-0998.

Desreumaux, P. \& Ghosh, S. (2006). Review article: mode of action and delivery of 5aminosalicylic acid - new evidence. Alimentary Pharmacology and Therapeutics, 24 Suppl 1, September 2006, 2-9, ISSN: 0269-2813.

Eaden, J.; Abrams, K.; Ekbom, A.; Jackson, E. \& Mayberry, J. (2000). Colorectal cancer prevention in ulcerative colitis: a case-control study. Alimentary Pharmacology and Therapeutics, 14, 2, February 2000, 145-153, ISSN: 1078-0998.

Eaden, J.; Abrams, K.R. \& Mayberry, J.J. (2001). The risk of colorectal cancer in ulcerative colitis: a meta-analysis. Gut, 48, 4, April 2001, 526-535, ISSN: 0017-5749.

Eaton, J.E.; Silveira, M.G.; Pardi, D.S.; Sinakos, E.; Kowdley, K.V.; Luketic, V.A.; Harrison, M.E.; McCashland, T.; Befeler, A.S.; Harnois, D.; Jorgensen, R.; Petz, J. \& Lindor, K.D. (2011). High-dose ursodeoxycholic acid is associated with the development of colorectal neoplasia in patients with ulcerative colitis and primary sclerosing cholangitis. The American Journal of Gastroenterology, May 2011 (in press), ISSN: 0002-9266.

Ekbom, A.; Helmick, C.; Zack, M. \& Adami, H.O. (1990). Ulcerative colitis and colorectal cancer. A population-based study. The New England Journal of Medicine, 323, 18, November 1990, 1228-1233, ISSN: 0028-4793.

Garrity-Park, M.; Loftus, E.V. Jr.; Sandborn, W.J. \& Smyrk, T.C. (2011). Myeloperoxydase immunohistochemitry as a measure of disease activity in ulcerative colitis: association with ulcerative colitis-colorectal cancer, tumor necrosis factor polymorphism and RUNX3 methylation. Inflammatory Bowel Disease, March 2011 (in press), ISSN: 1078-0998.

Gasche, C.; Chang, C.L.; Rhees, J.; Goel, A. \& Boland, C.R. (2001). Oxidative stress increases frameshift mutations in human colorectal cancer cells. Cancer Research, 61, 20, October 2001, 7444-7448, ISSN: 0008-5472.

Gerrits, M.M.; Chen, M.; Theeuwes, M.; van Dekken, H.; Sikkema, M.; Steverberd, E.W.; Lingsma, H.F.; Siersema, P.D.; Xia, B.; Kusters, J.G.; van der Woude, C.J. \& Kuipers, E.J. (2011). Biomarker-based prediction or inflammatory bowel disease-related colorectal cancer: a case-control study. Cellular Oncology (Dordrecht), 34, 2, April 2011, 107-117, ISSN: 2211-3436.

Giovannucci, E.; Stampfer, M.J.; Colditz, G.A.; Hunter, D.J.; Fuchs, C.; Rosner, B.A.; Speizer, F.E. \& Willett, W.C. (1998). Multivitamin use, folate, and colon cancer in women in the Nurses' Health Study. Annals of Internal Medicine, 129, 7, October 1998, 517-524, ISSN: 0003-4819. 
Giovannucci, E.; Stampfer, M.J.; Colditz, G.A.; Rimm, E.B.; Trichopoulos, D.; Rosner, B.A.; Speizer, F.E. \& Willett, W.C. (1993). Folate, methionine, and alcohol intake and risk of colorectal adenoma. Journal of the National Cancer Institute, 85, 11, June 1993, 875884, ISSN: 0027-8874.

Gupta, R.B.; Harpaz, N.; Itzkowitz, S.; Hossain, S.; Matula, S.; Kornbluth, A.; Bodian, C. \& Ullman, T. (2007). Histologic inflammation is a risk factor for progression to colorectal neoplasia in ulcerative colitis: a cohort study. Gastroenterology, 133, 4, October 2007, 1099-1105, ISSN: 0016-5085.

Harnois, D.M.; Angulo, P.; Jorgensen, R.A. ; Larusso, N.F. \& Lindor, K.D. (2001). Highdose ursodeoxycholic acid as a therapy for patients with primary sclerosing cholangitis. The American Journal of Gastroenterology, 96, 5, May 2001, 1558-1562, ISSN: 0002-9266.

Heuschen, U.A.; Hinz, U.; Allemeyer, E.H.; Stern, J.; Lucas, M.; Autschbach, F.; Herfarth, C. \& Heuschen, G. (2001). Backwash ileitis is strongly associated with colorectal cancer in patients with ulcerative colitis. Gastroenterology, 120, 4, March 2001, 841847, ISSN: 0016-5085.

Hofseth, L.J.; Saito, S.; Hussain, S.P.; Espey, M.G.; Miranda, K.M.; Araki, Y.; Jhappan, C.; Higashimoto, Y.; He, P.; Linke, S.P.; Quezado, M.M.; Zurer, I.; Rotter, V.; Wink, D.A.; Appella, E. \& Harris, C.C. (2003). Nitric oxide-induced cellular stress and p53 activation in chronic inflammation. Proceedings of the National Academy of Sciences of the United States of America, 100, 1, January 2003, 143-148, ISSN: 00278424.

Hudson, J.D.; Shoaibi, M.A.; Maestro, R.; Carnero, A.; Hannon, G.J. \& Beach, D.H. (1999). A proinflammatory cytokine inhibits p53 tumor suppressor activity. The Journal of Experimental Medicine, 190, 10, November 1999, 1375-1382, ISSN: 0022-1007.

Hussain, S.P.; Amstad, P.; Raja, K.; Ambs, S.; Nagashima, M.; Bennett, W.P.; Shields, P.G.; Ham, A.J.; Swenberg, J.A.; Marrogi, A.J. \& Harris, C.C. (2000). Increased p53 mutation load in noncancerous colon tissue from ulcerative colitis: a cancer-prone chronic inflammatory disease. Cancer Research, 60, 13, July 2000, 3333-3337, ISSN: 0008-5472.

Hussain, S.P.; Hofseth, L.J. \& Harris, C.C. (2003). Radical causes of cancer. Nature Reviews Cancer, 3, 4, April 2003, 276-285, ISSN: 1474-175X.

Jansson, E.A.; Are, A.; Greicius, G.; Kuo, I.C.; Kelly, D.; Arulampalam, V. \& Pettersson, S. (2005). The Wnt/beta-catenin signaling pathway targets PPARgamma activity in colon cancer cells. Proceedings of the National Academy of Sciences of the United States of America, 102, 5, February 2005, 1460-1465, ISSN: 0027-8424.

Kim, Y.I.; Pogribny, I.P.; Basnakian, A.G.; Miller, J.W.; Selhub, J.; James, S.J. \& Mason, J.B. (1997). Folate deficiency in rats induces DNA strand breaks and hypomethylation within the p53 tumor suppressor gene. The American Journal of Clinical Nutrition, 65, 1, January 1997, 46-52, ISSN: 0002-9165.

Kimura, H.; Hokari, R.; Miura, S.; Shigematsu, T.; Hirokawa, M.; Akiba, Y.; Kurose, I.; Higuchi, H.; Fujimori, H.; Tsuzuki, Y.; Serizawa, H. \& Ishii, H. (1998). Induced expression of an inducible isoform of nitric oxide synthase and the formation of peroxynitrite in colonic mucosa of patients with active ulcerative colitis. Gut, 42, 2, February 1998, 180-187, ISSN: 0017-5749. 
Kulaylat, M.N. \& Dayton, M.T. (2010). Ulcerative colitis and cancer. Journal of Surgical Oncology, 15, 8, June 2010, 706-712, ISSN: 0022-4790.

Lashner, B.A. (1993). Red blood cell folate is associated with the development of dysplasia and cancer in ulcerative colitis. Journal of Cancer Research and Clinical Oncology, 119, 9, September 1993, 549-554, ISSN: 0171-5216.

Lashner, B.A.; Heudenreich, P.A.; Su, G.L.; Kane, S.V. \& Hanauer, S.B. (1989) Effect of folate supplementation on the incidence of dysplasia and cancer in chronic ulcerative colitis. Gastroenterology, 97, 2, August 1989, 255-259, ISSN: 0016-5085.

Lashner, B.A.; Provencher, K.S.; Seidner, D.L.; Knesebeck, A. \& Brzezinski A. (1997). The effect of folic acid supplementation on the risk for cancer or dysplasia in ulcerative colitis. Gastroenterology, 112, 1, January 1997, 29-32, ISSN: 0016-5085.

Laurent, C.; Svrcek, M.; Flejou, J.F.; Chenard, M.P.; Duclos, B.; Freund, J.N. \& Reimund, J.M. (2011). Immunohistochemical expression of CDX2, $\beta$-catenin and TP53 in inflammatory bowel disease-associated colorectal cancer. Inflammatory Bowel Disease, 17, 1, January 2011, 232-240, ISSN: 1078-0998.

Lichtenstein, G.R. \& Rutgeerts, P. (2010). Importance of mucosal healing in ulcerative colitis. Inflammatory Bowel Disease, 16, 2, February 2010, 338-346, ISSN: 1078-0998.

Loftus, E.V. Jr.; Aguilar, H.I.; Sandborn, W.J.; Tremaine, W.J.; Krom, R.A.; Zinsmeister, A.R.; Graziadai, I.W. \& Wiesner, R.H. (1998). Risk of colorectal neoplasia in patients with primary sclerosing cholangitis and ulcerative colitis following orthotopic liver transplantation. Hepatology, 27, 3, March 1998, 685-690, ISSN: 0270-9139.

Lu, D.; Cottam, H.B.; Corr, M. \& Carson, D.A. (2005). Repression of beta-catenin function in malignant cells by nonsteroidal anti-inflammatory drugs. Proceedings of the National Academy of Sciences of the United States of America, 102, 51, December 2005, 1856718571, ISSN: 0027-8424.

Lutgens, M.W.; van der Heijden, G.J.; Vleggaar, F.D. \& Oldenburg, B. (2008) A comprehensive meta-analysis of the risk of colorectal carcinoma in ulcerative colitis and Crohn's disease. Gut, 57 (Suppl II), A131, ISSN: 0017-5749.

Lutgens, M.W.M.D.; Vleggaar, F.P.; Schipper, M.E.I.; Stokkers, P.C.F.; van der Woude, C.J.; Hommes, D.W.; de Jong, D.J.; Dijkstra, G.; van Bodegraven, A.A.; Oldenburg, B \& Samsom, M. (2008). High frequency of early colorectal cancer in inflammatory bowel disease. Gut, 57, 9, September 2008, 1246-1251, ISSN: 0017-5749.

Mardini, H.A.; Lindsay, D.C.; Deighton, C.M. \& Record, C.O. (1987). Effect of polymer coating on faecal recovery of ingested 5-aminosalicylic acid in patients with ulcerative colitis. Gut, 28, 9, September 1987, 1084-1089, ISSN: 0017-5749.

Matthissen, M.W.; Pedersen, G.; Albrektsen, T.; Adamsen, S.; Fleckner, J. \& Brynskov, J. (2005). Peroxisome proliferator-activated receptor expression and activation in normal colonic epithelial cells and tubular adenomas. Scandinavian Journal of Gastroenterology, 40, 2, February 2005, 198-205, ISSN: 0036-5521.

Moghal, N. \& Sternberg, P.W. (1999). Multiple positive and negative regulators of signaling by the EGF-receptor. Current Opinion in Cell Biology, 11, 2, April 1999, 190-196, ISSN: 0955-0674.

Monteleone, G.; Franchi, L.; Fina, D.; Carusao, R.; Vavassori, P.; Monteleone, I.; Calabrese, E.; Naccari, G.C.; Bellinvia, S.; Testi, R. \& Pallone, F. (2006). Silencing of SH-PTP2 
defines a crucial role in the inactivation of epidermal growth factor receptor by 5aminosalicylic acid in colon cancer cells. Cell Death and Differentiation, 13, 2, February 2006, 202-211, ISSN: 1350-9047.

Moody, G.A.; Jayanthi, V.; Probert, C.S.; Mac Kay, H. \& Mayberry, J.F. (1996). Long-term therapy with sulphasalazine protects against colorectal cancer in ulcerative colitis: a retrospective study of colorectal cancer risk and compliance with treatment in Leicestershire. European Journal of Gastroenterology and Hepatology, 8, 12, December 1996, 1179-1183, ISSN: 0954-691X.

Nuako, K.W.; Ahlquist, D.A.; Mahoney, D.W.; Schaid, D.J.; Siems, D.M. \& Lindor, N.M. (1998). Familial predisposition for colorectal cancer in ulcerative colitis: a casecontrol study. Gastroenterology, 115, 5, November 1998, 1079-1083, ISSN: 00165085.

Onizawa, M.; Nagaishi, T.; Kanai, T.; Nagano, K.; Oshima, S.; Nemoto, Y.; Yoshioka, A.; Totsuka, T.; Okamoto, R.; Nakamura, T.; Sakamoto, N.; Tsuchiya, K.; Aoki, K.; Ohya, K.; Yagita, H. \& Watanabe, M. (2009). Signaling pathway via TNF-alpha/NFkappaB in intestinal epithelial cells may be directly involved in colitis-associated carcinogenesis. American Journal of Physiology. Gastrointestinal and Liver Physiology, 296, 4, April 2009, G850-859, ISSN: 0193-1857.

Osawa, E.; Nakajima, A.; Wada, K.; Ishimine, S.; Fujisawa, N.; Kawamori, T.; Matsuhashi, N.; Kadowaki, T.; Ochiai, M.; Sekihara, H. \& Nakagama, H. (2003). Peroxisome proliferator-activated receptor gamma ligands suppress colon carcinogenesis induced by azoxymethane in mice. Gastroenterology, 124, 2, February 2002, 361-367, ISSN: 0016-5085.

Oshitani, N.; Kitano, A.; Okabe, H.; Nakamura, S.; Matsumoto, T. \& Kobayashi, K. (1993). Location of superoxide anion generation in human colonic mucosa obtained by biopsy. Gut, 35, 7, July 1993, 284-285, ISSN: 0017-5749.

Pardi, D.S.; Loftus, E.V. Jr.; Kremers, W.K.; Keach, J. \& Lindor, K.D. (2003). Ursodeoxycholic acid as a chemopreventive agent in patients with ulcerative colitis and primary sclerosing cholangitis. Gastroenterology, 124, 4, April 2003, 889893, ISSN: 0016-5085.

Phelip, J.M.; Ducros, V.; Faucheron, J.L.; Flourié, B. \& Roblin, X. (2008). Association of hyperhomocysteinemia and folate deficiency with colon tumors in patients with inflammatory bowel disease. Inflammatory Bowel Disease, 14, 2, February 2008, 242248, ISSN: 1078-0998.

Pinczowski, D.; Ekbom, A.; Baron, J.; Yuen, J. \& Adami, H.O. (1994). Risk factors for colorectal cancer in patients with ulcerative colitis: a case-control study. Gastroenterology, 107, 1, July 1994, 117-120, ISSN: 0016-5085.

Popivanova, B.K.; Kitamura, K.; Wu, Y. ; Kondo, K. ; Kagava, T.; Kaneko, S.; Oshima, M.; Fujii, C. \& Mukaida, M. (2008). Blocking TNF- $\alpha$ in mice reduces colorectal carcinogenesis associated with chronic colitis. The Journal of Clinical Investigation, 118, 2, February 2008, 560-570, ISSN: 0021-9738.

Rachmilewitz, D.; Stamler, J.S.; Bachwich, D.; Karmeli, F.; Ackerman, Z. \& Podolsky, D.K. (1995). Enhanced colonic nitric oxide generation and nitric oxide synthase activity in ulcerative colitis and Crohn's disease. Gut, 36, 5, May 1995, 718-723, ISSN: 00175749 . 
Ransohoff, D.F. (1988). Colon cancer in ulcerative colitis. Gastroenterology, 94, 4, April 1988, 1089-1091, ISSN: 0016-5085.

Rijk, M.C.; van Schaik, A. \& van Tongeren, J.H. (1988). Disposition of 5-aminosalicylic acid by 5-aminosalicylic acid-delivering compounds. Scandinavian Journal of Gastroenterology, 23, 1, January 1988, 107-112, ISSN: 0036-5521.

Roessner, A.; Kuester, D.; Malfertheiner, P. \& Schneider-Stock, R. (2008). Oxidative stress in ulcerative colitis-associated carcinogenesis. Pathology, Research and Practice, 204, 7, June 2008, 511-524, ISSN: 0344-0338.

Rousseaux, C.; Lefebvre, B.; Dubuquoy, L.; Lefebvre, P.; Romano, O.; Auwerx, J.; Metzger, D.; Wahli, W.; Desvergne, B.; Naccari, G.C.; Chavatte, P.; Farce, A.; Bulois, P.; Cortot, A.; Colombel, J.F. \& Desreumaux, P. (2005). Intestinal anti-inflammatory effect of 5-aminosalicylic acid is dependent on peroxisome proliferator-activated receptor-gamma. The Journal of Experimental Medicine, 201, 8, April 2005, 1205-1215, ISSN: 0022-1007.

Rutter, M.D.; Saunders, B.P.; Wilkinson, K.H., Rumbles, S.; Schofield, G.; Kamm, M.; Williams, C.B.; Price, A.B.; Talbot, I.C. \& Forbes, A. (2004a). Cancer surveillance in longstanding ulcerative colitis: endoscopic appearances help predict cancer risk. Gut, 53, 12, December 2004, 1813-1816, ISSN: 0017-5749.

Rutter, M.; Saunders, B; Wilkinson, K.; Rumbles, S.; Shofield, G.; Kamm, M.; Williams, C.; Price, A.; Talbot, I. \& Forbes, A. (2004b). Severity of inflammation is a risk factor for colorectal neoplasia in ulcerative colitis. Gastroenterology, 126, 2, February 2004, 451459, ISSN: 0016-5085.

Rutter, M.D.; Saunders, P.P.; Wilkinson, K.H.; Rumbles, S.; Schofield, G.; Kamm, M.; Williams, C.B.; Price, A.B.; Talbot, I.C. \& Forbes, A. (2006). Thirty years analysis of colonoscopic surveillance program for neoplasia in ulcerative colitis. Gastroenterology, 130, 4, April 2006, 1030-1038, ISSN: 0016-5085.

Sandborn, W.J. \& Hanauer, S.B. (2003). Systematic review: the pharmacokinetic profiles of oral mesalazine formulations and mesalazine pro-drugs used in the management of ulcerative colitis. Alimentary Pharmacology and Therapeutics, 17, 1, January 2003, 2942, ISSN: 1078-0998.

Shimada, T.; Kojima, K.; Yoshiura, K.; Hiraishi, H. \& Terano, A. (2002). Characteristics of the peroxisome proliferator receptor gamma (PPARgamma) ligand induced apoptosis in colon cancer cells. Gut, 50, 5, May 2002, 658-664, ISSN: 0017-5749.

Sjöqvist, U.; Tribukait, B.; Ost, A.; Einarsson, C.; Oxelmark, L. \& Löfberg, L. (2004). Ursodeoxycholic acid treatment in IBD patients with colorectal dysplasia and/or DNA-aneuploidy: a prospective, double-blind, randomized controlled pilot study. Anticancer Research, 24, 5B, September-October 2004, 3121-3127, ISSN: 0250-7005.

Sokol, H.; Cosnes, J.; Chazouillieres, O.; Beaugerie, L.; Tiret, E.; Poupon, R. \& Seksik P. (2008). Disease activity and cancer risk in inflammatory bowel disease associated with primary sclerosing cholangitis. World Journal of Gastroenterology, 14, 22, June 2008, 3497-3503, ISSN 1007-9327.

Stolfi, C.; Fina, D.; Caruso, R.; Caprioli, F.; Sarra, M.; Fantini, M.C.; Rizzo, A.; Pallone, F. \& Monteleone, G. (2008). Cyclooxygenase-dependent and -independent inhibition of 
proliferation of colon cancer cells by 5-aminosalicylic acid. Biochemical Pharmacology, 75, 3, February 2008, 668-676, ISSN: 0006-2952.

Svrcek, M; Cosnes, J.; Tiret, E.; Bennis, M.; Park, Y. \& Flejou, J.F. (2007). Expression of epidermal growth factor receptor (EGFR) is frequent in inflammatory bowel disease (IBD)-associated intestinal cancer. Virchows Archives, 450, 2, February 2007, 243-244, ISSN: 0945-6317.

Tanaka, T.; Kohno, H.; Yoshitani, S.; Takashima, S.; Okumura, A.; Murakami, A. \& Hosokawa, M. (2001). Ligands for peroxisome proliferator-activated receptors alpha and gamma inhibit chemically induced colitis and formation of aberrant crypt foci in rats. Cancer Research, 61, 6, March 2001, 2424-2428, ISSN: 0008-5472.

Terdiman, J.P.; Steinbuch, M.; Blumentals, W.A.; Ullman, T.A. \& Rubin, T.D. (2007). 5aminosalicylic acid therapy and the risk of colorectal cancer among patients with inflammatory bowel diseases. Inflammatory Bowel Disease, 13, 367-371, ISSN: 10780998.

Torres, J.; de Chambrun, G.P.; Itzkowitz, S.; Sachar, D.B. \& Colombel, J.F. (2011). Review article: colorectal neoplasia in patients with primary sclerosing cholangitis and inflammatory bowel disease. Alimentary Pharmacology and Therapeutics, June 2011 (in press), ISSN: 0269-2813.

Van Hogezand, R.A.; van Hees, P.A.; van Gorp, J.P.; van Lier, H.J.; Bakker, J.H.; Wesseling, P.; van Haelst, U.J. \& van Tongeren, J.H. (1988). Double-blind comparison of 5aminosalicylic acid and acetyl-5-aminosalicylic acid suppositories in patients with idiopathic proctitis. Alimentary Pharmacology and Therapeutics, 2, 1, February 1988, 33-40, ISSN: 1078-0998.

van Staa, T.P.; Card, T.; Logan, R.F. \& Leufkens, H.G.M. (2005). 5-Aminosalicylate use and colorectal cancer risk in inflammatory bowel disease: a large epidemiological study. Gut, 54, 11, November 2005, 1573-1578, ISSN: 0017-5749.

Velayos, F.S.; Loftus, E.V. Jr.; Jess, T.; Harmsen, W.S.; Bida, J.; Zinsmeister, A.R.; Tremaine, W.J. \& Sandborn, W.J. (2006). Predictive and protective factors associated with colorectal cancer in ulcerative colitis: a case-control study. Gastroenterology, 130, 7, June 2006, 1941-1949, ISSN: 0016-5085.

Velayos, F.S.; Terdiman, J.P. \& Walsh, J.M. (2005). Effect of 5-aminosalicylate use on colorectal cancer and dysplasia risk: a systematic review and metaanalysis of observational studies. The American Journal of Gastroenterology, 100, 6, June 2005, 1354-1356, ISSN: 0002-9266.

Viennot, S.; Deleporte, A.; Moussata, D.; Nancey, S.; Flourié, B. \& Reimund, J.M. (2009). Colon cancer in inflammatory bowel disease: recent trends, questions and answers. Gastroentérologie Clinique et Biologique, 33 Suppl 3, June 2009, S190-201, ISSN: 03998320.

Vree, T.B.; Dammers, E.; Exler, P.S.; Sorgel, F.; Bondesen, S. \& Maes, R.A. (2000). Liver and gut mucosa acetylation of mesalazine in healthy volunteers. International Journal of Clinical Pharmacology and Therapeutics, 38, 11, November 2000, 514-522, ISSN: 09461965.

Winther, K.V.; Jess, T.; Langholz, E.; Munkholm, P. \& Binder, V. (2004). Long-term risk of cancer in ulcerative colitis: a population-based cohort study from Copenhagen County. Clinical Gastroenterology and Hepatology, 2, 12, December 2004, 1088-1095, ISSN: 1542-3565. 
Wolf, J.A.; Rybicki, L.A. \& Lashner, B.A. (2005). The impact of ursodeoxycholic acid on cancer, dysplasia and mortality in ulcerative colitis patients with primary scleosing cholangitis. Alimentary Pharmacology and Therapeutics, 22, 9, November 2005, 783788, ISSN: 1078-0998.

Yakut, M.; Ustün, Y.; Kabaçam, G. \& Soykan, I. (2010). Serim vitamin B12 and folate status in patients with inflammatory bowel disease. European Journal of Internal Medicine, 21, 4, August 2010, ISSN: 0953-6205. 


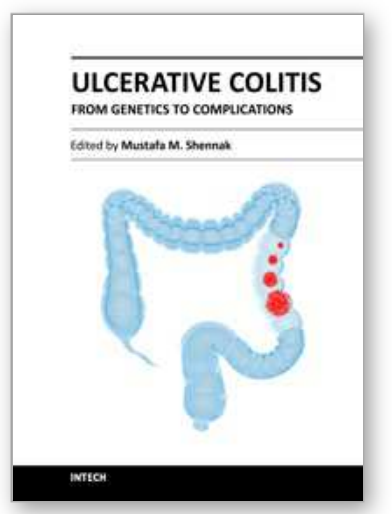

\author{
Ulcerative Colitis from Genetics to Complications \\ Edited by Prof. Mustafa Shennak
}

ISBN 978-953-307-853-3

Hard cover, 222 pages

Publisher InTech

Published online 18, January, 2012

Published in print edition January, 2012

Ulcerative Colitis (UC) is a rapidly evolving medical field, and will continue to be very exiting in the next few decades. Although the underlying cause of this disease is still unknown, results in research dealing with various issues related to this disease are published every day. Chapters included in this book review the most recent literature on related advancements in regard to this chronic disease, which is controllable but not curable. Aspects like epidemiology, pathophysiology, genetics, incriminated etiologies, clinical aspects, complications, and disease management, including advancements in the diagnostic and therapeutic options, were documented by well known clinicians, researchers, and world wide authorities in their fields. This book on UC will be a valuable addition to each doctor's library interested in this subject, or for physicians dealing with patients suffering from this disease. Authors have also included figures and diagrams to depict their point, and to easily reach the minds of the readers in the simplest way.

\title{
How to reference
}

In order to correctly reference this scholarly work, feel free to copy and paste the following:

Jean-Marie Reimund, Marion Tavernier, Stéphanie Viennot, Inaya Abdallah Hajj Hussein, Benoît Dupont, Anne-Marie Justum, Abdo R. Jurjus, Jean-Noël Freund and Mathilde Lechevrel (2012). Ulcerative ColitisAssociated Colorectal Cancer Prevention by 5-Aminosalicylates: Current Status and Perspectives, Ulcerative Colitis from Genetics to Complications, Prof. Mustafa Shennak (Ed.), ISBN: 978-953-307-853-3, InTech, Available from: http://www.intechopen.com/books/ulcerative-colitis-from-genetics-to-complications/ulcerativecolitis-associated-colorectal-cancer-prevention-by-5-aminosalicylates-current-status-and-

\section{INTECH}

open science | open minds

\section{InTech Europe}

University Campus STeP Ri

Slavka Krautzeka 83/A

51000 Rijeka, Croatia

Phone: +385 (51) 770447

Fax: +385 (51) 686166

www.intechopen.com

\section{InTech China}

Unit 405, Office Block, Hotel Equatorial Shanghai

No.65, Yan An Road (West), Shanghai, 200040, China 中国上海市延安西路65号上海国际贵都大饭店办公楼 405 单元

Phone: +86-21-62489820

Fax: $+86-21-62489821$ 
(C) 2012 The Author(s). Licensee IntechOpen. This is an open access article distributed under the terms of the Creative Commons Attribution 3.0 License, which permits unrestricted use, distribution, and reproduction in any medium, provided the original work is properly cited. 